\title{
METHOD OF EVALUATION OF THE TECHNICAL CONDITION OF THE DIESEL-ELECTRIC UNIT
}

\author{
MARCIN ZACHAREWICZ, Tomasz KNIAZIEWICZ \\ Polish Naval Academy, M.Zacharewicz@amw.gdynia.pl \\ Polish Naval Academy, T.Kniaziewicz@amw.gdynia.pl
}

Abstract

The article presents an innovative method of evaluating technical condition of marine diesel engines driving electric power generator. The presented method is based on measurements of the phase-to-phase voltage of the synchronous generator and on measurements of the acceleration of the injector needle. The basis for the method is an assumption that the shapes of the waveforms of the phase-to-phase voltage of the generator include information on fluctuations of the angular velocity of the engine crankshaft. Consequently, these fluctuations depend directly on the course of the working process occurring in the engine cylinders. The vibrating signal is used to synchronize the shapes of the voltage waveforms with the engine working process.

Keywords: marine diesel engines, diagnostic, diesel-electric unit

\section{METODA OCENY STANU TECHNICZNEGO OKRĘTOWEGO ZESPOŁU SPALINOWO- ELEKTRYCZNEGO}

\section{Streszczenie}

W artykule przedstawiono nowatorską metodę oceny stanu technicznego okrętowych tłokowych silników spalinowych o zapłonie samoczynnym napędzających prądnice. Prezentowana metoda bazuje na pomiarach napięcia międzyfazowego prądnicy synchronicznej oraz na pomiarze przyspieszeń iglicy wtryskiwacza. Podstawą metody jest założenie, że przebiegi napięcia międzyfazowego prądnicy zawierają informację o fluktuacjach prędkości kątowej wału korbowego silnika. Natomiast fluktuacje te zależą bezpośrednio od przebiegu procesu roboczego realizowanego w cylindrach silnika. Sygnał drganiowy wykorzystywany jest do synchronizacji przebiegów napięcia z cyklem roboczym silnika.

Słowa kluczowe: Okrętowy tłokowy silnik spalinowy, diagnostyka, zespół spalinowo-elektryczny

\section{INTRODUCTION}

At present majority of the main engines operated on ships of the Navy of the Republic of Poland is covered by the strategy of operation according to their technical condition. This results from their high diagnostic susceptibility [14, 15]. However, a large number of the engines, mainly auxiliary ones is not covered with this strategy. This results from their low diagnostic susceptibility as they are not equipped with indicator valves. These are mainly engines cooperating with synchronous generators (making up the so-called diesel-electric units DG). They are operated according to the strategy providing periodical replacement of their sub-units following a schedule imposed by the manufacturer. This is connected with necessity to replace their component parts regardless of their actual technical condition.

The issue of evaluation of technical condition of the engines of low diagnostic susceptibility has been the object of research conducted by a Scientific Team of the Institute of Ship
Construction and Operation at the Polish Naval Academy. The outcome of their development work was a few methods enabling evaluation of technical condition of the engines under consideration. One of the methods is the evaluation of technical condition of a marine diesel engine based on measurements of pressure in the exhaust outlet ducts $[16,17,28]$. The outcome of the conducted research is also a method of evaluating technical condition of the bearing nodes of the engine based on measurements of pressure indicated for the engine operating without a torque load [27]. In addition, research is conducted on the development of methods based on acceleration measurements of designated structural elements of the engine [11]. Similar research is also conducted at other academic centres both in Poland and abroad. Studies on the assessment of the technical condition of engines based on acceleration and aquatics measurements are particularly popular $[4,5,11$, 32]. Another popular method of assessing the technical condition of engines is their indication [22, 23, 26]. Optical studies using endoscopes to assess the surface condition of engine working 
spaces are also popular [15]. In addition, optical tests are carried out around the world using ultrafast cameras to analyse the working process in the engine $[1,2]$.

The core insufficiency of the majority of the mentioned methods is necessity to intervene into the engine construction elements.

The method presented in the article allows to evaluate the course of the working process in an engine based on measurements of the phase-tophase voltage of the generator and those of the injector needle acceleration. This does not require any modification of the examined diesel-electric unit. This does not require disassembly of its elements, either [30].

\section{ASSUMPTIONS OF THE METHOD}

The basic assumption of the method of evaluating technical condition of marine diesel engines driving synchronic generators on the basis of measurements of the phase-to-phase voltage is as follows:

The technical condition of an engine exerts direct impact on the course of the working process occurring in the engine cylinders. Consequently it has an impact on fluctuations of the angular velocity of its crankshaft $[3,9,10]$. Fluctuations of the angular velocity of the crankshaft translate into fluctuations of the angular velocity of the generator rotor. They influence the shapes of the waveform of the phase-to-phase voltage of the generator. From the timing shapes of the waveforms of the phase-tophase voltage it is then possible to isolate information on the technical condition of the engine driving a generator.

\section{DEVELOPMENT OF THE METHOD}

A research program was proposed in order to develop the new method of evaluating technical condition of the engines making part of the dieselelectric units [29]. The base for the development were diesel-electric units used at the Marine Electrical Equipment Operation Laboratory of the Polish Naval Academy. On the basis of the said units a physical model [8] of the processes occurring in the engine cylinders was developed. This was the basis to develop a mathematical model and a computer software based on it $[7,12,13]$. At each stage of the model development (physical, mathematical and computer software) known and recognizable engine defects were introduced such as: change in the fuel rate, fuel injection advance, changes in the active valve cross-section area, etc. Application of the defects was possible for each one cylinder independently.

In addition, an adjuster of the engine rotational speed was applied to the engines of both full and partial technical fitness. The basis for modelling the rotational speed adjuster operation was an assumption that both in case of the technically fit engine and in case of a defective engine the flow rate of the fuel mass should be supplied to the cylinders in such an amount so that the total indicated power of the cylinders of both the technically fit and defective engine are equal [12, 30]. Another promising method developed in the world is the research of the relationship between the emission of toxic compounds and the technical condition of the engine [19, 24].

A model was also developed for an engine of a high diagnostic susceptibility. This was caused by the fact that in case of such an engine it was possible to perform evaluation of its adequacy.

The developed models were evaluated against their adequacy. The evaluation was conducted on the basis of a comparative analysis of the proposed measures [29] based on measurements of parameters obtained as a result of empirical and modelling tests. After achieving satisfactory adequacy (both quantitative and qualitative) the next step was to complete the developed model with equations describing the operation of the synchronous generator. Then, the developed equations were implemented in the computer software. After this stage another evaluation of the adequacy was conducted in comparison with the real object. This required development of measures allowing to compare timing course of the phase-tophase voltage obtained as a result of the modelling and empirical tests.

\section{MODELLING AND EMPIRICAL RESEARCH}

In order to evaluate adequacy of the developed diesel-electric unit modelling and empirical examinations were conducted. The same research program was adopted in respect to both real object and the model $[14,18,25]$. It was assumed that a piston-type engine $6 \mathrm{SW} 400$ would be loaded with the use of a resistance receiver. The adopted values of loading with the receiver were: $2 \mathrm{~kW}, 10 \mathrm{~kW}$ and $20 \mathrm{~kW}$. In case of the engine, defects were simulated by cutting off one or two cylinders from operation. The cutting off the cylinders from operation was done by switching off a high pressure conduit from the injector [31]. The test plan was presented in Table 1.

Within the scope of the conducted tests the values of the phase-to-phase voltage were measured for phases: $\mathrm{L}_{1}-\mathrm{L}_{2}, \mathrm{~L}_{2}-\mathrm{L}_{3}$ and $\mathrm{L}_{3}-\mathrm{L}_{1}$. In addition, accelerations in the axis of the needle operation of a selected engine injector was measured.

The measurement of accelerations, because of its periodical nature corresponding to the engine working cycle, was used as a reference signal. It allowed to synchronize the recorded shapes of the waveforms of the phase-to-phase voltage with the engine working cycle. 
Table 1.Test plan for the diesel-electric unit

\begin{tabular}{|c|c|}
\hline $\begin{array}{c}\text { Loading with the power of } \\
\text { electric receivers }\end{array}$ & $\begin{array}{c}\text { Number of } \\
\text { measurement }\end{array}$ \\
\hline \multicolumn{2}{|c|}{ Engine fit for use } \\
\hline $2 \mathrm{~kW}$ & 1 \\
\hline $10 \mathrm{~kW}$ & 2 \\
\hline $20 \mathrm{~kW}$ & 3 \\
\hline Cylinder no. 1 cut off from operation \\
\hline $2 \mathrm{~kW}$ & 4 \\
\hline $10 \mathrm{~kW}$ & 5 \\
\hline $20 \mathrm{~kW}$ & 7 \\
\hline \multicolumn{2}{|c|}{ Cylinder no. 6 cut off from operation } \\
\hline $2 \mathrm{~kW}$ & 8 \\
\hline $10 \mathrm{~kW}$ & 9 \\
\hline $20 \mathrm{~kW}$ & 10 \\
\hline Cylinders no. 1 and 6 cut off from operation \\
\hline $2 \mathrm{~kW}$ & 11 \\
\hline $10 \mathrm{~kW}$ & 12 \\
\hline $20 \mathrm{~kW}$ &
\end{tabular}

The measurements and recording of the selected parameters were carried out with the use of a device allowing for galvanic separation between the values of the phase-to-phase voltages of the generator and the measurement card. The consequence of the application of the device was addition of a constant component to the recorded shapes of the waveforms. All measurements (of the phase-tophase voltage and accelerations) were carried out at the same time with a sampling frequency of $10 \mathrm{kHz}$ and a resolution of 12 bit. An example of synchronically averaging shape of the waveforms of the phase-to-phase voltage recorded during the tests is shown in Fig. 1. The shape of the waveforms of accelerations measured in the axis of the injector operation is shown in Fig. 2.

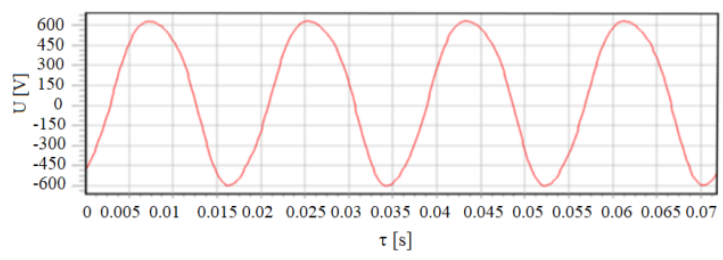

Fig. 1. The shape of the waveforms of the line-to-line voltage as a function of time recorded during the measurements for the engine loaded with receivers of $22 \mathrm{~kW}$

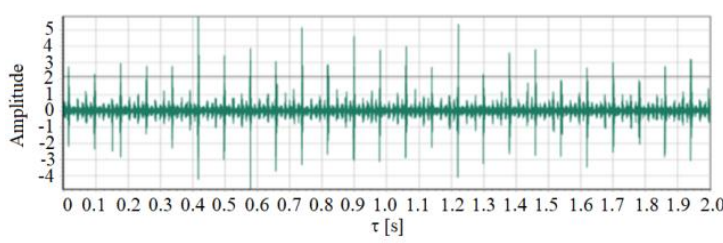

Fig. 2. The shape of the waveforms of the signal amplitude value from the acceleration metre installed in the axis of the injector needle

The shapes of the waveforms of the phase-tophase voltage obtained as a result of the conducted tests essentially differ from theoretical ones described by the sinus function (for the unit operating at a constant angular velocity of the generator rotor).

To carry out the analysis of the shapes of the waveforms of the phase-to-phase voltage it was necessary to find measures describing deformation of the recorded shape of the waveforms relative to the theoretical one. With this purpose in mind measure $\mathrm{Z}$ was proposed. It was based on a comparison of the standard shape of the waveforms and that recorded during the modelling or empirical tests. In order to obtain the standard shape of the waveforms of the phase-to-phase voltage Fourier transform was adopted. As a result of its application coefficients $\mathrm{a}_{1}$ and $\mathrm{a}_{2}$ were calculated on the basis of equations 1 and 2 .

$$
\begin{gathered}
a_{1}=\frac{2}{T} \cdot \int_{-\frac{T}{2}}^{\frac{T}{2}} f(\tau) \cdot \cos \left(\frac{2 \cdot \pi}{T}\right) \mathrm{d} \tau \\
b_{1}=\frac{2}{T} \cdot \int_{-\frac{T}{2}}^{\frac{T}{2}} f(\tau) \cdot \sin \left(\frac{2 \cdot \pi}{T}\right) \mathrm{d} \tau \\
U_{\mathrm{wz}}=\frac{a_{0}}{2}+a_{1} \cdot \cos \left(\frac{2 \cdot \pi}{T} \cdot \tau\right)+b_{1} \cdot \sin \left(\frac{2 \cdot \pi}{T} \cdot \tau\right)
\end{gathered}
$$

Next, on the basis of the Fourier reverse transform, described by equation 3 the shape of the waveforms recognized as standard was obtained. Fig. 3 shows a fragment of the recorded shape of the waveforms of the phase-to-phase voltage - shape 1 and the standard shape -2 .

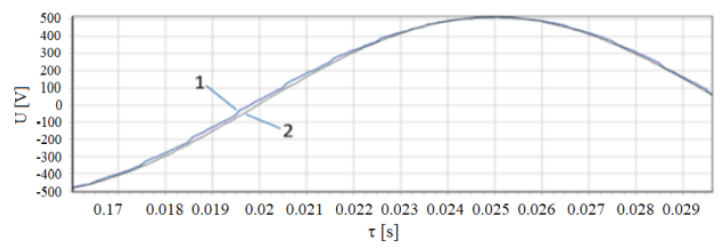

Fig. 3. Fragment of the recorded shape of the waveforms of the line-to-line voltage as

a function of time 1 - the shape obtained from measurements, 2 - the standard shape

Further on, values of differences between the shapes of the waveforms of the phase-to-phase were determined, i.e.: recorded and standard. The differences were determined for each time value (with a resolution of $10 \mathrm{kHz}$ ) in relation to the recorded shape of the waveforms. The method is illustrated in Fig. 4.

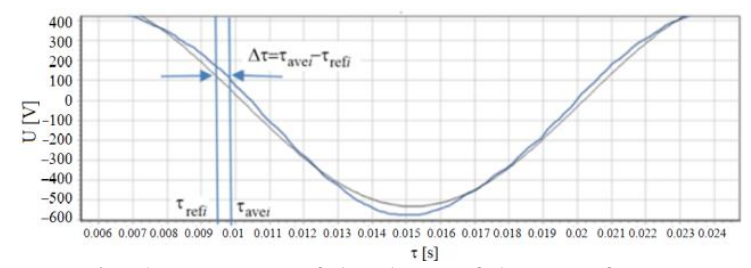

Fig. 4. Fragment of the shape of the waveforms of the phase-to-phase voltage of

a generator with the marked method of calculating the values of increase

In case of the analysed shapes of the waveforms it was observed that the values of the time differences $\Delta \tau$ were not linear. Their highest values occur within the vicinity where the values of the phase-to- 
phase voltage were $0 \mathrm{~V}$. However, these values decreased once they are near the maximum and minimum values. (Fig. 4). In order to minimize the influence of non-linearity, proportional coefficient was applied described by the equation:

$$
w s p_{\tau}=\frac{a_{0}}{2}+a_{1} \cdot \cos ^{2}\left(\frac{2 \cdot \pi}{T} \tau\right)+b_{1} \cdot \sin ^{2}\left(\frac{2 \cdot \pi}{T} \tau\right)
$$

Analysing the shapes of the waveforms shown in Fig. 4 it can be observed that, within the scope of the highest values of the amplitude of the phase-tophase voltage there may be areas for which it is not possible to satisfy condition $U_{\text {ave } i} \approx U_{\text {ref } i}$. In this case it was decided to assume the value of time difference $\Delta \tau_{i}$ as equal to „100" - the difference of such value does not occur during the tests then it may play a role of a marker.

Further, an average value of time difference $\Delta \tau_{i}$ was determined for all the shapes of the waveforms of the phase-to-phase voltages (three). Within the areas where the value $\Delta \tau_{i}=100$ an average of the two shapes of the waveforms of the phase-to-phase voltages was determined (the areas where the condition $\left.U_{\text {ave } i} \approx U_{\text {ref } i}\right)$ was not satisfied was omitted.

The averaged shapes of the waveforms for time differences $\Delta \tau$ as a function of time is shown in Fig. 5.

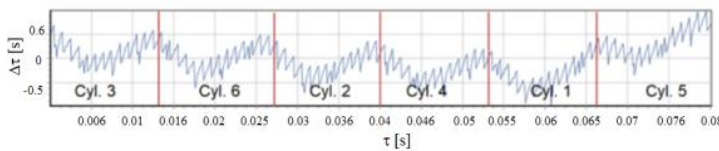

Fig. 5. The shapes of the waveforms of time differences as a function of time for the engine with a damaged cylinder no. 1

(measurement of the injector accelerations was applied to cylinder no. 3)

The value of measure $\mathrm{Z}$ is determined for each one engine cylinder. It is described by the equation:

$$
Z_{i}=\int_{\tau_{\mathrm{open} i}}^{\tau_{\mathrm{open} i+1}} \Delta \tau(\tau) d \tau
$$

where value $\tau_{\text {open } i}$ denotes the time of the injector opening of the $\mathrm{i}^{\text {th }}$ cylinder, while $\tau_{\text {open } i+1}$ denotes the time of the opening of a subsequent injector following the successive operation of the engine cylinders.

An example of the course of the measure $Z$ value for the damaged engine is shown in Fig. 6.

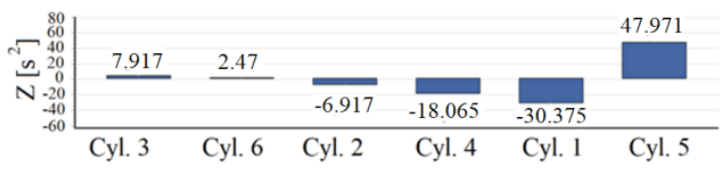

Fig. 6. Measure $\mathrm{Z}$ as a function of time for particular engine cylinders for the damaged engine (cutting off fuel supplying cylinder no. 1)
The obtained results of the modelling and empirical tests [29] allowed to find that the developed model of the diesel-electric unit is qualitatively adequate. This means that both in case of the modelled unit and in case of the real object the values of measure $\mathrm{Z}$ are convergent for respective cylinders.

On the other hand, however, the quantitative evaluation is problematic which is a result of the applied measuring devices (using transoptors for galvanic separation) $[6,7]$. They introduce a certain non-linearity. In addition, it was found that frequency of sampling was too low what can be seen on the example of the course shown in Fig. 5. In case of the adequacy evaluation of the developed model it was observed that when the load of the DG with the use of receivers increases the adequacy of the model also increases. In addition, very high variances between the values of measure $\mathrm{Z}$ for each tested DG were observed (empirical tests).

Nonetheless, on the basis of the obtained results it was possible to develop a method of evaluating technical condition of the engine making part of the diesel-electric units on the basis of measurements of the generator phase-to-phase voltage.

It was observed that in each case, failure of any of the cylinder sections causes a significant change of measure $\mathrm{Z}$ both in the area of the damaged cylinder and also in other cylinders. The values of measure for damaged cylinders are always negative, while, as a result of the operation of the rotational velocity adjuster the values of measures of the remaining cylinders have, as a rule, higher values than those occurring in an engine fit for use.

When developing the method of evaluating technical condition of an engine it was required to find an unambiguous measure informing on the damage and allowing to identify the cylinder section where failure occurred. It was decided to divide the process of evaluating the technical condition into two basic stages:

- Stage One - to find whether a damage occurs in case of the tested diesel-electric unit,

- Stage Two - to locate the damage by pointing to a specific cylinder section.

At stage One it was decided to use the value of the standard deviation - $\sigma$ calculated for measures $\mathrm{Z}$ with respect to each one cylinder, what is described by the following equation:

$$
\sigma=\sqrt{\sum_{j=1}^{N} \frac{\left(Z_{j}-\bar{Z}\right)^{2}}{j}}
$$

This stage is based on the observation made with regard to the value of the standard deviation of measure $\mathrm{Z}$ for an engine under various technical fitness for use. It was observed that in case of the damaged engine the standard deviation assumes the value higher than in case of the engine fit for use for the same loads. This results from higher fluctuations of the angular velocity of the crankshaft resulting in a higher range of the value 
of measure $\mathrm{Z}$. The values of the standard deviations for cylinders of an engine in various fitness condition have been shown in Table 2 .

Table 2. Summary of the standard deviation values for various technical conditions of the engine

\begin{tabular}{|l|c|c|c|c|}
\hline \multirow{2}{*}{$\begin{array}{c}\text { Technical conditions and } \\
\text { loads }\end{array}$} & \multicolumn{3}{|c|}{$\begin{array}{c}\text { Empirical tests for } \\
\text { unit no.: }\end{array}$} & $\begin{array}{c}\text { Mod } \\
\text { el }\end{array}$ \\
\cline { 2 - 4 } & 1 & 2 & 3 & \multirow{2}{*}[\sigma]{} \\
\cline { 2 - 4 }$[\sigma]$ & {$[\sigma]$} & {$[\sigma]$} & \\
\hline Fit $-2 \mathrm{~kW}$ & 5.9 & 5.5 & 6.2 & 2.5 \\
\hline Cyl. 1 off $-2 \mathrm{~kW}$ & 10.7 & 8.9 & 8.4 & 5.4 \\
\hline Cyl. 6 off - 2 kW & 7.3 & 7.8 & 6.4 & 5.9 \\
\hline Cyl. 1 \& 6 off - 2 kW & 6.8 & 4.9 & 5.3 & 5.7 \\
\hline Fit - 10 kW & 8.9 & 8.7 & 7.2 & 0.7 \\
\hline Cyl. 1 off - 10 kW & 15.1 & 11.6 & 15.3 & 11.5 \\
\hline Cyl. 6 off - 10 kW & 13.7 & 16.1 & 11.8 & 11.9 \\
\hline Cyl. 1 \& 6 off - 10 kW & 11.0 & 10.4 & 10.5 & 10.7 \\
\hline Fit - 20 kW & 8.6 & 7.6 & 5.9 & 1.8 \\
\hline Cyl. 1 off - 20 kW & 22.7 & 17.8 & 19.1 & 21.5 \\
\hline Cyl 6 off - 20 kW & 18.1 & 23.0 & 18.8 & 22.2 \\
\hline Cyl. 1 \& 6 off - 20 kW & 16.4 & 18.2 & 19.7 & 19.6 \\
\hline
\end{tabular}

On the basis of the value of the standard deviation of measure $\mathrm{Z}$ it was possible to decide whether the engine was fit for use or damaged. At the same time it could be observed that variances of the values of the standard deviation for the damaged engine increased with the increase of the generator load with receivers. It was assumed that in case of the generator loaded with $10 \mathrm{~kW}$ and 20 $\mathrm{kW}$ receivers the value of the standard deviation of less than 10 relates to the engine in which no damage was applied, while the value of the deviation higher than 10 demonstrates damage in the engine.

Stage Two is based on the observation that in case of the damaged engine the values of measure $\mathrm{Z}$ for damaged cylinders are significantly higher than the value of the standard deviation. The value of measure $\mathrm{Z}$ for cylinders not damaged also exceeds the range of the standard deviation, however, the absolute value of measure $\mathrm{Z}$ is smaller for them than those occurring in case of damaged engines. The value of measure $\mathrm{Z}$ in case of cylinders with the applied damage (for one cylinder cut off) each time exceeds the value of product $1.5 \cdot \sigma$. On the other hand, in case of the non-damaged cylinders in no case under the tests the value of the adopted measure exceeded product $1.5 \cdot \sigma$. On the basis of the observation made it was assumed that the measure allowing to identify each one damaged cylinder is information whether any of the measures $\mathrm{Z}$ exceeds value $1.5 \cdot \sigma$. Its excess explicitly demonstrates that the cylinder is cut off the operation. If this condition is not satisfied this may demonstrate that the damage does not occur or the number of damaged cylinders is larger.

Using information obtained at Stage One of the analysis (whether damage occurs or not) and knowing whether measure $\mathrm{Z}$ exceeds the value by one-and-half value standard deviation it is possible to make difference between the fit for use engine and the engine with the number of damaged cylinders greater than one. In case of damage to greater number of the engine cylinders an unambiguous indication which of the cylinders is damaged is possible. While conducting the analysis, the value of the standard deviation $-\sigma$, instead of the product $1.5 \cdot \sigma$ should be used for identification of the damaged cylinders. A diagram for processing in case of analysing measured data and diagnosing on the damaged cylinders has been presented in a form of an algorithm for the proceeding. See: Fig. 7.

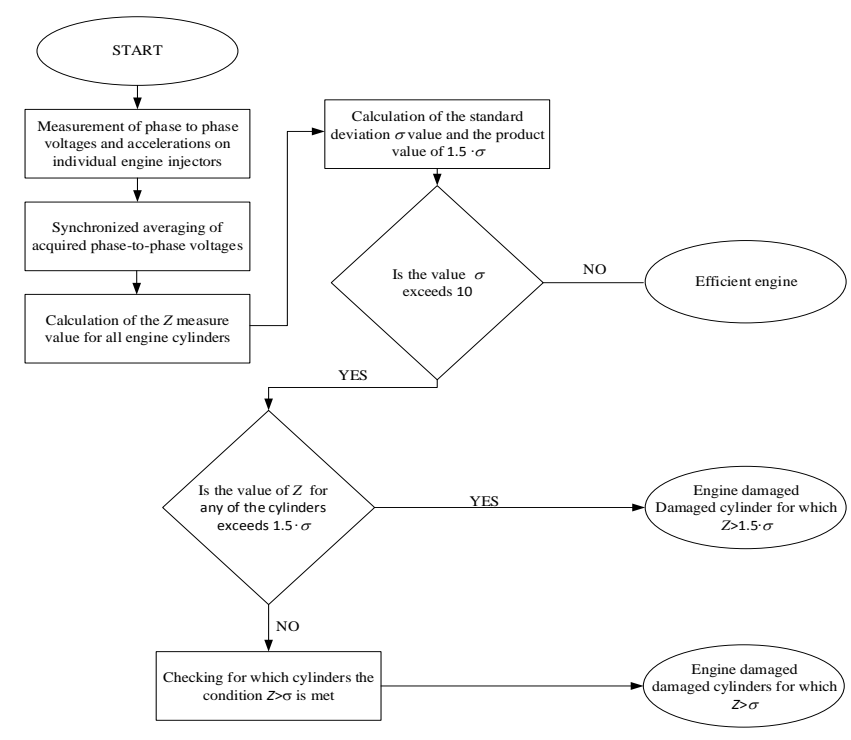

Fig. 7. Algorithm for evaluating technical condition of an engine used for driving synchronous electric power generators based on the shapes of the waveforms of its phase-to-phase voltage

Apart from the described modelling and empirical research it was decided to conduct research on models for the conditions of partial technical fitness by:

- Reducing fuel rate supplied to the cylinders by $10 \%, 20 \%, 30 \%, 40 \%$ and $50 \%$ as compared with nominal rate.

- Reducing the angle of the fuel injection advance by $5^{\circ} \mathrm{CA}$.

- Increasing the angle of the fuel injection advance by $5^{0} \mathrm{CA}$.

- Introduction of untightness in the piston-ringscylinder set amounting to $5 \%$ of the maximum area of the outlet valve diameter.

- Reducing the area of diameter of the injector holes by $10 \%$ and $20 \%$.

- Increasing the area of diameter of the injector holes by $10 \%$ and $20 \%$.

All tests were conducted for two loads of the electric power generator with electric receivers of a power of 10 and $20 \mathrm{~kW}$.

In the described case resignation from empirical tests was a result of necessity to intervene into the engine (in order to simulate its partial 
technical condition) what could possibly lead to its damage.

The modelling tests carried out allowed to draw the following specific conclusions [31]:

- Simulated conditions of partial technical fitness for use by reducing the fuel rate supplied to the damaged cylinder and the simulated untightness in the piston-rings-cylinder set may be detected and located with the developed method.

- Condition that make the engine not fit for use resulting from the change of the area of the active diameter of the active cross-section of the injector holes and the change in the advance angle of the injection for the damaged engine cause certain deviations in the measure $Z$ value as compared with the engine fit for use. However, the values of these deviations are minimal and consequently, this damage, probably, may not be detected with the use of the proposed method.

- Impossibility to identify part of the damage may be caused by relatively low signal sampling frequency amounting to $10 \mathrm{kHz}$. Because of the compatibility of the data obtained from empirical and modelling tests the results obtained from the model have the same sampling frequency as measured data.

\section{SUMMARY}

In the article it has been demonstrated that the proposed method for evaluating the technical condition of an engine is efficient in case of identification and location of the engine cylinders where the working process is disrupted to a higher degree. In case of a damage consisting of cutting off the engine cylinders the operation, each time it is possible to identify and locate the damage. The modelling tests demonstrated that it is possible to identify damage as a result of reducing fuel rate supplied to the engine cylinders. In case of other simulated damage, at current stage of the research it is not possible to identify the damage. This is a result of a relatively small sampling frequency of the measured (modelled) courses.

Further work on the developed method will be directed to increase the sampling frequency of the measuring device (development of a new device) and to reduce steps of calculations in the model (currently calculations are performed every 0.1 $\left.{ }^{0} \mathrm{CA}\right)$.

\section{REFERENCES}

1. Agatrwal Z, Jiotode Y, Sharman N. Endoscopic visualization of engine combustion chamber using diesoline, diesoline and mineral diesel for comparative spatial soot and temperature distributions. Fuel, 2019;241: 901-913. https://doi.org/10.1016/j.fuel.2018.11.068

2. Agarval A, Singh A, Agarval A. Evolution, Trends and Applications of Endoscopy in Internal
Combustion Engine. Journal of Energy and Environmental Sustainability, 2016; 1: 56-66

3. Biocanin S, Biocain M. Measurement Crankshaft Angular Speed of an OM403 Engine. Serbian Journal of Electrical Engineering, 2017;14(2):257-275. https://doi.org/10.2298/SJEE1702257B

4. Cavina N, Businaro A, Rojo N, Cesare M, Paiano L, Cerofolini A. Combustion and Intake/Exhaust systems diagnosis based on acoustic emissions of a GDI TC engine. Energy Procedia 2016;101:677-684. https://doi.org/10.1016/j.egypro.2016.11.086

5. Chiatti G, Chiavola O, Recco E, Magno A, Mancaruso E, Vaglieco B. Accelerometer measurement for MFB evaluation in multi-cylinder diesel engine. Energy, 2017; 133:843-850. https://doi.org/10.1016/j.energy.2017.04.148

6. Cwalina A, Zacharewicz M. Conception and practical application of a measuring device for energetic parameters measurement of a mechatronic object. Solid State Phenomena 2012:180: 185-193.

7. Cwalina A, Kniaziewicz T, Zacharewicz M. Problems of mathematical modelling of the marine diesel engine working cycle for the diagnostic purposes. Solid State Phenomena 2015; 236: 212219.

8. Cwalina A, Zacharewicz M. Research on energetic processes in a marine diesel engine driving a synchronous generator for diagnostic purposes Part 1 - Physical model of the processes. Journal of Polish CIMAC 2013;8(1): 99-104.

9. Dereszewski M, Charchalis A, Model based prediction of the crankshaft instantaneous angular speed fluctuations. Journal of KONES Powertrain and Transport 2013;20(1). https://doi.org/10.5604/12314005.1135314

10. Guerrero D, Jimenez-Espadafor R. Torsional system dynamics of low speed diesel engines based on instalaneous torque: Application to engine diagnosis. Mechanical System and Signal Processing 2019; 116: 858-878. https://doi.org/10.1016/j.ymssp.2018.06.051

11. Kluczyk M, Grządziela A. Vibration diagnostics of the naval propulsion systems. Scientifc Journal of Polish Naval Academy 2017; 1(208): 15-29.

12. Kniaziewicz T, Zacharewicz M. Mathematical modelling malfunctions of marine diesel engine. MATEC Web conf 2017; 118: 1-5. https://doi.org/110.1051/matecconf/201711800001

13. Kniaziewicz T, Zacharewicz M. Evaluation of adequacy of a model of a naval reciprocating internal combustion engine developed for the needs of diagnostic tests. Scientific Journal of the Maritime Academy 2018; 108: $67-80$.

14. Korbicz J, Kościelny JM, Kowalczuk Z, Cholewa W. Diagnostyka procesów. WNT, Warszawa 2002.

15. Korczewski Z. Operational diagnostics of marine diesel engines - piston and turbine: selected issues. Wydawnictwo PG 2017.

16. Korczewski Z, Zacharewicz M. Alternative diagnostic method applied on marine diesel engines having limited monitoring susceptibility. SAGE Publications 2012. Transaction of the Institute of Measurement and Control, 2012; 34: 937-946.

17. Korczewski Z, Zacharewicz M. A method for diagnosis of naval ships' engines of a limited possibility to measure pressures inside cylinders on the basis of the results of testing gas-dynamic processes in the supercharge system. Polish Naval 
Academy, Gdynia 2008. Research Project no.: OT00B02129.

18. Kothari C. Research methodology methods and techniques (Third Edition), New age international publishers, 2015

19. Kowalski J. Concept of the multidimensional diagnostic tool based on exhaust gas composition for marine engines. Applied Energy, 2015; 150: 1-8. https://doi.org/10.1016/j.apenergy.2015.04.013

20. Mikulski M, Wierzbicki S. Validation of a zerodimensional and 2-phase combustion model for dualfuel compression ignition engine simulation. Thermal Science. 2017;21(1B):387-399. http://dx.doi.org/10.2298/TSCI160127076M

21. Niziński S, Wierzbicki S. Zintegrowany system informatyczny sterowania pojazdów. Diagnostyka. 2004; 30:47-52.

22. Pawletko R. Increasing the accuracy of the mean indicated pressure determination by appointment of the TDC cylinder position. Journal of KONES Powertrain and Transport 2014; 21(4): 397-404. https://doi.org/10.5604/12314005.1130494

23. Pawletko R, Polanowski S. Evaluation of current developments and trends in the diagnosis of marine diesel engines based on the indicator diagrams analysis. Journal of KONES Powertrain and Transport 2014; 21(4): 389-396. https://doi.org/110.5604/12314005.1130492

24. Toma M, Micu D, Andreescu C. Influences of engine faults on pollutant emission. Procedia Manufacturing 2018; 32: 529-536. https://doi.org/10.1016/j.promfg.2019.02.249

25. Walliman N. Research methods the basic, Taylor \& Francis Group, 2011. https://doi.org/10.4324/9780203836071

26. Witkowski K. The issue of the indicator diagram analysis for the purpose of diagnosis of marine diesel engines. Journal of KONES Powertrain and Transport 2015; 22(2):293-298. https://doi.org/110.5604/12314005.1165456

27. Wontka L. Mecha onical losses as a diagnostic parameter of the technical condition of a reciprocating internal combustion engine. Polish Naval Academy 2017; Dissertation.

28. Zacharewicz M. A method of diagnosing workin spaces of a marine engine based on gas-dynamic parameters in the duct suppying the turbo-charger. Polish Naval Academy 2009; Dissertation.

29. Zacharewicz M. Possibilities of parametric evaluation of technical condition of a marine reciprocating internal combustion engine of a low diagnostic susceptibility. Polish Naval Academy, Gdynia 2019,

30. Zacharewicz M, Kniaziewicz T. Research on energetic processes in a marine diesel engine driving a synchronous generator for diagnostic purposes. Part 2 - mathematical model of the processes. Journal of Polish CIMEEAC 2016; 11(1):199-209.

31. Zacharewicz M, Kniaziewicz T, Cwalina A. Asseement of technical condition of marine auxiliary diesel engine on the basis of electrical measurements of synchronous generator. Combustion Engines 2015; 54/3(162): 170-176.

32. Żółtowski B, Żółtowski M. Vibration signals in mechanical engineering and construction. ITE-PIB, Radom, 2015.

Received 2019-02-13

Accepted 2019-05-27

Available online 2019-05-28

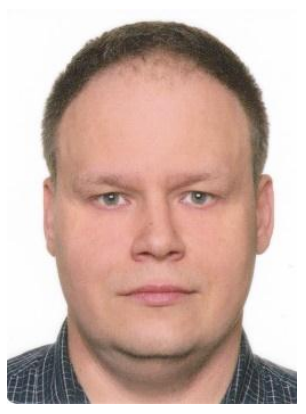

PhD. Marcin

ZACHAREWICZ is an assistant professor in the Faculty of Mechanical and Electrical Engineering in Polish Naval Academy. He served on: fast attack craft ORP "Władysławowo" as Chief Engineer and submarine ORP "ORZEŁ" as Engineer. Over 15 years he has working in Polish Naval Academy in Gdynia. His main work concerns the modelling of processes occurring in ship engines for the purpose of diagnosing them.

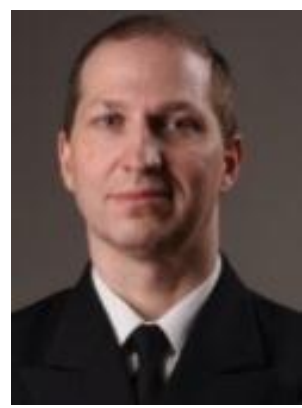

DSc., DEng. Tomasz

KNIAZIEWICZ is a

Professor in the Faculty of Mechanical and Electrical Engineering and ViceRector for Science in Polish Naval Academy. He served on corvette ORP "Kaszub" as Chief Engineer. Over 25 years he has working in Polish Naval Academy in Gdynia. His major works are devoted to emission of toxic compounds in the exhaust of marine diesel engines. 